\title{
Politics and Social Spending in Latin America
}

\author{
Evelyne Huber, University of North Carolina at Chapel Hill \\ Thomas Mustillo, Indiana University at Indianapolis \\ John D. Stephens, University of North Carolina at Chapel Hill
}

We acknowledge the support of National Science Foundation Grant \#SES-0241389. We would also like to thank Alexander Hicks, Robert Kaufman, Victoria Murillo, Kurt Weyland, and the participants in the Comparative Politics Working Group at the University of North Carolina, Chapel Hill, for comments on previous drafts. Huber and Stephens thank the Hanse Institute for Advanced Study in Delmenhorst, Germany, for support and a stimulating environment in which to work on this study, as well as UNC Chapel Hill for research and study leaves. 


\section{Abstract \\ Politics and Social Spending in Latin America}

We examine the determinants of social expenditure in an unbalanced pooled time series analysis for 18 Latin American countries for the period 1970 to 2000 . This is the first such analysis of spending in Latin American countries with a full complement of regime, partisanship, state structure, economic, and demographic variables, making our analysis comparable to analyses of welfare states in advanced industrial countries. Democracy matters in the long run both for social security and welfare and for health and education spending, and - in stark contrast to OECD countries - partisanship does not matter.

Highly repressive authoritarian regimes retrench spending on health and education, but not on social security. 
Expenditures on social security and welfare, health, and education are an essential part of what governments do to enhance the quality of life of their citizens and the human capital base of their societies. Social scientists have developed a strong body of theory and evidence to understand social expenditures as part and parcel of welfare state development. Most of this theory has been built on the basis of studies of welfare states in OECD countries and emphasizes mobilization of social groups and the role of political parties and institutions, along with economic and demographic factors, as determinants of welfare state formation. Our central question is to what extent this theory travels to different contexts and how it needs to be modified for the study of social expenditures in Latin America.

Our focus on social expenditures in Latin America is governed by the concern with building on extant theory and developing mid-range theories of welfare state development across regions. In order to do so, we need to study regions that exhibit social policy regimes that can be usefully compared with those in OECD countries. Only in Latin America do we find as early as the 1970s social policy regimes with a long history that covered a majority of their populations against social risks and thus deserve to be conceptualized as welfare states. However, we emphasize that there is great variation in social policy regimes within Latin America, ranging from Uruguay and Argentina, where a large majority of the population remains covered by social security schemes and enjoys decent education and health services, to El Salvador and Guatemala, where social security schemes and quality education and health care reach less than $40 \%$ of the population. 
Similarly, since the OECD welfare state literature emphasizes political variables political parties, political institutions (federalism, corporatism), policy legacies (the emergence of stake holders in social policy schemes) - we need to study a region where there is variation in these variables and they can be studied over a significant period of time. For parties and subnational levels of government to develop and shape politics, democracy is a prerequisite. In the $20^{\text {th }}$ century, Latin America was the non-OECD region with the most extensive experience with democracy, both full and restricted democracy. At the same time, Latin America experienced a variety of non-democratic regimes, from highly repressive authoritarianism to populist regimes with authoritarian traits. Thus, Latin America provides us with some comparability to OECD countries, but in contrast to the latter, Latin America also provides great variation in regime forms.

In this article we suggest the following theoretical modifications in theories of welfare state development to adapt them to the study of social expenditures in Latin America: First and foremost, we need to incorporate regime form as an independent variable. The countries included in the major studies of OECD welfare states have had uninterrupted democratic rule since WWII, whereas the Latin American countries have experienced periods of more and less repressive authoritarianism and full or restricted democracy. Clearly, we want to understand whether and how these regime forms shape social expenditure patterns.

Second, we need to take into account that the role of political parties may play out differently in different economic and social structures and in the presence of different policy legacies. Parties have been shown to be the key factors shaping the generosity and redistributive profile of welfare states in OECD countries. Latin American parties with 
the same general value commitments and policy preferences as their OECD counterparts, however, may face different constraints, leading to different effects on social expenditure patterns. Of particular importance are differences in the historical strength of democracy, civil society, and parties themselves, which in turn shaped differences in the historical formation of social security systems and thus the policy legacies in terms of their distributional impact and clienteles. Also, the severity of economic pressures has constituted a more important influence on social expenditures than in OECD countries.

\section{Theory and Hypotheses}

There are only a few studies of the determinants of social expenditures and their composition in Latin America that we might build on (Avelino et al. 2005; Brown and Hunter 1999, 2004; Kaufman and Segura 2001; Wibbels 2006). Moreover, they all use a lagged dependent variable or first differences for the dependent variable. This essentially means that their analyses are analyses of changes in spending from one year to the next. We, in contrast, are interested in the determinants of long-term patterns of social expenditures which are indicated by levels of expenditure. This choice makes our analysis comparable to studies of social spending in OECD countries, the vast majority of which use levels as well. Similarly, we are interested in the long-run effects of political variables. We would not expect one year of democracy or of dominance of one political tendency or another in the legislature and/or the executive to make a major difference in the formation of social policy. We have shown elsewhere that an extrapolation of shortterm effects to the long-term greatly underestimates the impact of political party dominance on expenditure patterns in OECD countries (Huber and Stephens 2001: 77). 
What matters for the achievement of different levels of social expenditures is the cumulative record of democracy and strength of different political forces.

Our theoretical point of departure is the insight of the welfare states literature that political power distributions and institutions have profoundly shaped the generosity and structure of welfare states in OECD countries. Arguably the most fundamental set of institutions shaping access to and the exercise of political power is regime form. Access to power is broader and more competitive under democratic than under authoritarian regimes, and the exercise of power is more accountable under the former than under the latter. Accordingly, we would expect democracies to be more likely to produce policies that benefit broad sectors of the population than authoritarian regimes. Specifically, we expect a positive effect of democracy on social security and welfare expenditures, as well as on health and education expenditures.

The question of the impact of regime forms on social policy is not confined to the comparison between democratic and non-democratic regimes. Not all non-democratic regimes have the same goals and use the same strategies and tactics. In post-WWII Latin America, non-democratic regimes ranged from reformist and minimally repressive (e.g. Perón in his second term, the Peruvian military government under Velasco) to reactionary and highly repressive regimes (the bureaucratic-authoritarian regimes of the Southern cone, e.g. Chile under Pinochet, and the military regimes and dictatorships in Central America). While the former regimes tolerated and at times encouraged popular organization and protected or even increased social spending levels, the latter used repression to weaken popular forces and their capacity to challenge the existing socioeconomic order and make claims on the state. They let real wages deteriorate and 
reduced the resources devoted to satisfying popular claims. Accordingly, we would expect a negative effect of highly repressive authoritarian regimes on social expenditures. When repressive authoritarian regimes are replaced by democratic regimes, the latter face spending levels depressed far below what is acceptable to the voters. Therefore, we expect a legacy of repressive authoritarianism that will fade over time.

Democracy is also a precondition for the emergence of strong parties and pressure groups capable of shaping public policy. Only prolonged democratic rule makes it possible for parties to consolidate as organizations and establish connections to civil society. This is particularly true for parties representing the interests of the underprivileged; that is, parties of the left. Authoritarian regimes may create parties to provide support for the regime, but in Latin America most authoritarian regimes actively suppressed the left. Democracy also allows for the strengthening of a variety of groups in civil society that represent lower class interests and may attempt to influence policy.

From the OECD welfare state literature we know that the strength of party blocs with different worldviews, value commitments, and constituencies is crucial for the amount and structure of social expenditures. Long-term incumbency of left-wing parties results in generous, highly inclusive and redistributive welfare states, with extensive public provision of free or subsidized social services. Long-term incumbency of secular right and center parties results in residual, non-generous welfare states, with heavy reliance on means testing and scanty financing and provision of social services. Longterm incumbency of Christian democratic parties results in generous welfare states, but with a less inclusive and redistributive profile, and with heavy reliance on private provision of publicly financed or mandated services (Bradley et al. 2003; Castles 1982; 
Hicks and Mishra 1993; Huber, Ragin and Stephens 1993; Huber and Stephens 2001; Swank 1992).

The strong effects of long-term party incumbency stem from the pursuit of policies motivated by different commitments to fundamental values and core constituencies. Both experts and politicians place parties on a left-right continuum defined primarily by their views of the socio-economic order (Castles and Mair 1984; Coppedge 1997; Alcántara and Freidenberg 2001). Parties compete on other issues, of course, such as urban versus rural, ethnicity and religion, or authoritarianism versus democracy, but these other cleavage structures vary considerably across countries whereas the left-right division is present everywhere in West European (Lijphart 1981) and Latin American (Alcántara and Rivas 2006) party systems.

Parties of the left are committed to the values of equality and solidarity, or in operational terms to using the state to reduce inequality by intervening in the economy and providing redistributive transfers and social services. Parties of the right come in two varieties - traditional and liberal. Both kinds are committed to the value of hierarchy, but the traditional conservatives accept paternalism and the use of the state to preserve the economic and social order, whereas the liberals espouse individualism and freedom from state interference in the economy. In operational terms, both kinds of conservatives use the state to protect economic winners by keeping direct taxation low and providing few transfers and social services, or giving them a non-redistributive profile. Christian democratic parties are committed to an organic world view, where the community has a responsibility to provide for all of its members, working on the subsidiarity principle which holds that the state only steps in where the family and the community are unable to 
provide (van Kersbergen 1995). However, they vary greatly in their commitments to equality, particularly in Latin America (Mainwaring and Scully 2003).

Of course, parties have other value commitments that are relevant for social policy, particularly for health and education policy, such as progress, development, and nationalism, but the commitments to progress and development are shared across the party spectrum to a greater extent than commitments to equality and solidarity. Therefore, to the extent that these other commitments influence social expenditure policies, we would expect them to work in the same direction of increasing expenditures on health and education and thus to reduce inter-party differences. The most relevant difference between parties with respect to social policy, and in particular its distributive profile, is their location on the left-right continuum.

A brief justification of our focus on political parties is in order, given that some scholars have argued that parties in Latin America are comparatively weak, have little programmatic cohesion and only shallow roots in civil society, and relate to their base largely through clientelism (e.g. Ameringer 1992, Ames 1995, Mainwaring and Torcal 2006). First, social science is cumulative and we want to understand the kinds of effects parties have on the same kinds of policies under different structural and historical conditions. Second, other scholars have demonstrated that at least by the end of the $20^{\text {th }}$ century some parties in some Latin American countries clearly mattered. Luna and Zechmeister (2005) have shown on the basis of elite and mass survey evidence that there is meaningful variation across countries in their sample of the extent to which parties cohere programmatically and represent the voters' policy preferences. Moreover, Colomer and Escatel (2004) demonstrate on the basis of data from Latinobarometer 
surveys from 1995 to 2002, for 17 Latin American countries, that an average of $78 \%$ of citizens are able to place themselves on a left-right scale. Finally, scholars have demonstrated the impact of partisan preferences on policy formation in Latin America. Gibson (1997) traces the connection between policy and electoral coalitions in the shaping of market reforms, and Murillo (2001) discusses the behavior of labor unions and partisan coalitions in such reforms.

The ability of parties with different positions on the left-right scale to shape policy in accordance with their underlying and enduring value commitments in the postWW II period has to be understood within the context of economic development strategies, the structure of the labor market, and policy legacies. The roots of the Latin American social security systems are in the Bismarckian occupationally based model, later disseminated through the International Labor Office (ILO). Social security schemes were first established for privileged groups (military, police, judiciary, civil servants) and later extended to crucial white collar (teachers, bank employees) and blue collar (miners, railroad workers, port workers) categories, and finally to formal sector employees in general. In the pioneer countries, this process began in the 1920s and accelerated in the 1940s and 1950s, linked to import substitution industrialization (ISI). A second group of countries followed suit some two decades later, and in the least developed countries coverage of social security schemes remained highly limited (Mesa-Lago 1978; 1989: 36).

The main political constellations under which social security schemes were expanded beyond privileged groups consisted of democratic regimes under left-leaning parties with autonomous labor movements (factions of the Colorados in Uruguay; PLN in 
Costa Rica), or regimes with close ties to organized labor, democratic (the Popular Front and the Unidad Popular in Chile), semi-democratic (Perón in Argentina), or authoritarian (Vargas in Brazil, PRI in Mexico). The degree of fragmentation and inequality of the social security schemes varied, but all systems had privileged schemes for the military and various categories of civil servants and all of them were overall regressive.

In this context, the preferences of parties of the left were for gradual expansion of the social security system, first to blue collar workers and then to those in the informal sector, along with unification and improvement of the benefits in the general system. ${ }^{1}$ Parties of the right preferred to protect fragmentation and the benefits in the privileged systems, but reducing social security expenditures was not a priority before the debt crisis of the 1980s and the opening of the Latin American economies. As long as ISI was pursued, social security schemes for private sector workers were financed mainly by employee and employer contributions. Indeed, in several countries employer contributions reached rather high levels, comparable to European levels. The reason why this was politically feasible was that employers, protected by high tariff walls, were able to pass these costs on to the consumers.

The debt crisis of 1982 and the ensuing neoliberal structural adjustment policies changed the situation radically. As protectionist barriers were lowered or removed, employers pressed for a lowering of their contributions to social security schemes. As unemployment and informalization spread, employee contributions and coverage declined, and the social security systems faced fiscal crises, aggravating the general fiscal crises faced by Latin American states. Thus, reduction of social expenditures in general and social security expenditures in particular became a priority for the right. The Chilean 
model of pension privatization - heavily promoted by the World Bank - became the reform of choice for neoliberals on the right. It is important to keep in mind, though, that the transition costs of such reforms were and still are substantial. Accordingly, even radical changes in the social security systems did not translate into a radical lowering of expenditures in the short run.

The left rejected privatization and preferred reforms aimed at the construction of unified public systems with strong basic benefits. Moreover, as the loss of formal sector employment left an increasing proportion of the population without social security coverage and as poverty levels rose, expansion of non-contributory social benefits assumed growing priority for the left. However, left and right were extremely constrained in finding resources for social policy. Thus, the actual policy differences between left and right concerned the allocation of social security expenditures more so than their magnitude, and we adopt a non-directional hypothesis for the impact of partisan political strength in the legislature on the overall amount of social security and welfare spending.

The reality of social security spending in Latin America at the beginning of the $21^{\text {st }}$ century is that it is still regressive. The bulk of social security spending goes to pensions, and the remainder to a few other kinds of transfers such as family allowances and maternity benefits. Social assistance is grouped with social security and welfare spending in our data, but it accounts for less than 20 percent of the total in this category only. $^{2}$ In the great majority of countries social security coverage remains confined to formal sector employees, which means that often $20 \%$ to $60 \%$ of the economically active population remained excluded. De Ferranti et al. (2004: 268-72), in a study for the World 
Bank, reviewed a range of studies and found that in most countries in Latin America the regressive components of social security spending outweigh progressive components. Lindert et al. (2005) confirm this assessment on the basis of their analysis of micro-data. ECLAC (2002:28) similarly shows that social security spending provides greater benefits to middle and upper strata.

There are a number of cash transfer programs that are grouped under social security but are not employment-based and earnings-related and are progressive, such as non-contributory pensions and some conditional cash transfers. They generally are highly progressive and have additional beneficial effects insofar as the conditions for receipt are school attendance and primary health care visits of children. The conditional cash transfer programs reviewed by Morley and Coady (2003), however, are limited in coverage and financing, reaching a maximum of $0.2 \%$ of GDP. Non-contributory, means-tested social assistance pensions are still relatively scarce and poorly funded as well (Muller 2005). In the past few years, under the left-wing governments in Brazil, Uruguay, and Chile, these programs have been expanded considerably. They are clearly a highly effective means to redistribute income and reduce poverty, but in the period covered by our data they still account for a small percentage of social security and welfare spending only. Nevertheless, there is considerable variation in the allocation of social security and welfare expenditures between countries, and indeed we have demonstrated elsewhere that a left-leaning balance of power in the legislature is associated with lower income inequality in Latin American and Caribbean countries (Huber, Nielsen, Pribble and Stephens 2006). If we had a measure for the overall distributive impact of social security and welfare expenditures, we would hypothesize a 
positive effect of a left-leaning partisan balance, but for the overall level of expenditures we adopt a non-directional hypothesis.

The development of health care systems in Latin America is linked to the development of social security schemes. In many cases, health care insurance has paralleled social security in the sense that part of employer and employee social security contributions have gone to health insurance. In some cases, care has been provided by social security clinics and hospitals, in other cases by private clinics and hospitals under contract with the social security system, and in still others by public clinics and hospitals. Public health expenditures have sometimes subsidized social security health care and always supported public clinics and hospitals and preventive health campaigns, and in some countries social security systems have provided health care on a non-contributory basis. In general, in line with the interests of their primary constituencies - blue collar workers and the poor in the case of left-of-center parties, and middle and upper income groups in the case of right-of-center parties - left parties have favored an improvement of the public health care system and right parties have favored private provision and private or social security financing. However, where formal sector employment was high and social security financing of health care had been established for some sectors of the work force, left-of-center parties supported expansion of employment-based insurance linked to private non-profit provision of care to reach virtually universal coverage (as in Argentina and Uruguay).

The educational system in Latin America shows a similar combination of private and public provision. At the primary and secondary level, private school attendance-heavily in Catholic schools--has been the norm rather than the exception for the middle 
and upper classes. At the university level, public universities played a prominent role. Catholic universities have a long tradition, but the proliferation of other private universities is a fairly recent phenomenon. Improvements in public education have been a consistent program point of the left, whereas the right has supported parents' choice between private and public schools - a choice heavily contingent on income.

There are regressive components of health and education expenditures, but in general the progressive components tend to outweigh the regressive ones (de Ferranti et al. 2004: 263-4). Studies of different programs show that expenditures on tertiary education are regressive, whereas basic education and health services provided by the public sector for the uninsured and school nutritional programs have a progressive incidence (e.g. Scott 2003 for Mexico; Wodon et al. 2003). ECLAC data for eight countries in the region show that the most progressive types of expenditures are spending on primary and secondary education, and that public spending on health care and nutrition is the second most progressive category (2002: 26). Lindert et al. (2005) conclude that the bulk of education spending has a generally progressive profile and health spending has a slightly progressive or neutral profile. Thus, on balance, we expect a positive effect of left-leaning dominance in the legislature on health and education expenditures.

Federalism has been held responsible in OECD countries for slowing the expansion of the public sector in general and the welfare state in particular (Schmidt 1997; Castles 1999; Obinger, Leibfried, and Castles 2005). Federalism and other institutional arrangements that provide veto points provide the opportunity for opponents of legislation to mobilize attempts to block its passage and thus make the adoption - but 
also the curtailment - of important social policy schemes more difficult (Bonoli and Mach 2000; Hicks 1999; Huber, Ragin and Stephens 1993; Huber and Stephens 2001; Maioni 1998; Swank 2002).

In general, federalism is likely to have a stronger impact on expenditure patterns under democratic rule, when constitutional provisions are followed. It has the strongest potential to serve as a brake on expansion or retrenchment of social spending if the representatives of subnational units have a share of formal and real decision-making power. However, it is theoretically possible that subnational powerholders under authoritarian regimes may have bargaining leverage with the central government and use that leverage to extract more resources from the center for social expenditures. This would be particularly likely to occur under relatively open, non-repressive authoritarian regimes, or authoritarian regimes that allow for some kinds of elections. Accordingly, we investigate the impact of federalism regardless of regime type, as well as the impact of federalism under democracy only. Since our period of analysis, 1970 to 2000, includes both phases when expansion and retrenchment were on the agenda (though more of the latter), the positive and negative effects could counterbalance each other and statistically this may result in no significant effects.

Our control variables include economic and demographic factors that affect both the needs for social expenditures and governmental capacity to meet those needs. We expect a positive effect of GDP per capita, urbanization, and the proportion of the elderly population on social security spending in Latin American countries. We also expect a positive effect of GDP per capita, urbanization, and size of the school age population on health and education spending. Given the contradictory nature of findings in previous 
studies, we adopt a non-directional hypothesis for the effect of trade openness on both types of spending. We expect a negative effect of FDI on social security spending and a positive one on health and education spending because of the importance of human capital for employers needing to be competitive in the world economy. Fiscal deficits sooner or later call for austerity policies and we would expect them to have negative effects on both social security/ welfare and health/ education expenditures. We would also expect presence of an IMF agreement to be associated with lower levels of both social security/ welfare and health/ education expenditures.

If one considers trajectories of macroeconomic and fiscal management in Latin America over the last three decades of the $20^{\text {th }}$ century, it is clear that they went through three clearly distinct phases. The 1970s were a period of slowed growth but continued expansion of budgets based on easy borrowing on international markets. The 1980s were the period of the debt crisis, economic contraction, budgetary austerity, and reverse capital flows from Latin America to the creditor countries. In the early 1990s the budgetary constraints eased as capital began to flow back to Latin America and economic growth resumed. Starting in the mid-1990s a number of financial crises had regional ripple effects and slowed growth again. These trends affected all the countries in the region, though with somewhat different timing and to different degrees. Therefore, if we take the 1970s as a baseline, we would expect a negative period effect for 1982-1989 (the first and last years for which the average growth rates in the region were negative) on levels of social spending. The expectations for the 1990s are more ambiguous; the 1990s were clearly an expansionary phase, but there was a lot of ground to make up and it is not clear whether most countries surpassed the levels of social expenditures of the 1970s. 


\section{Measures of the Dependent and Independent Variables}

Our measures of social spending as a percentage of GDP are derived from several sources (see Table 1). The measure of social security and welfare is from the IMF. The measure of health and education spending combines data from ECLAC, Cominetti (1996), ECLAC's Social Panorama, and the IMF. The construction of the health and education series and the methodology for dealing with the varied sources are explained in the appendix available at our web site (http://www.unc.edu/ jdsteph/index.html). Our detailed analysis of the sources showed that the Cominetti health and education series was significantly higher than the others, so a dummy variable for that data source is included in the analysis of health and education spending.

Our measure of democracy is based upon the classification of regime types in Rueschemeyer et al. (1992), updated according to those coding rules. Colonies and all kinds of authoritarian regimes are coded as 0 , restricted democracies as .5 , and full democracies as 1 . The measure cumulates the annual series since 1945 , to capture the strength of the democratic record in the post-WW II period. ${ }^{3}$

We coded repressive authoritarian regime as a separate category, using 1 for every year where the country had a repressive authoritarian regime and 0 for every year without such a regime; authoritarian regimes were coded as repressive if they committed or tolerated widespread human rights violations. Yearly scores were cumulated over the 5 years prior to the year of observation. We reason that the effects of authoritarian rule would fade through time. ${ }^{4}$ (See Appendix Table 1 at http://www.unc.edu/ jdsteph/index.html for regime classifications.)

Our political variables are derived from Coppedge (1997). In his project, he consulted country experts to classify political parties which contested elections for the 
lower house or constituent assemblies in 11 countries of Latin America from as far back as $1912 .^{5}$ His classification scheme contains two primary dimensions and several residual categories. First, it includes a left-right dimension, defined primarily in social and economic terms. He is concerned with a political party's ideology and class appeals and with its relative prioritization of growth and redistribution. This dimension is divided into five categories: left, center-left, center, center-right, and right. Second, it includes a religious dimension of two categories, Christian and secular. It distinguishes those parties which do and do not base their ideology or programs in the Catholic Church, the Bible, or religious philosophy or seek to defend the interests of the Catholic Church and to reduce the separation of church and state. Finally, his classification scheme contains three residual categories: personalist, other, and unknown. For our purposes, it is sufficient to say that these residual categories all contain parties that are not classifiable according to left-right or Christian-secular criteria.

In two respects, we rather directly adopted his work. First, we adopted his classification scheme. ${ }^{6}$ Second, in all but one case, we adopted his classification of parties for the country-years that fall within our sample. We make one revision: Coppedge classified the Peronists of Argentina as "other," while we classify them as secular center-left during the democratic episodes between 1945 and 1973; as secular center during the democratic years from 1974 to 1989; and as secular center-right from 1990 onward. $^{7}$

We use his classification scheme to expand the coverage to the full range of countries and years that fall within our analysis. ${ }^{8}$ After classifying each party, we summed the proportion of the seats held by each category for each country-year. ${ }^{9}$ This 
results in 13 annual series (secular left, secular center-left, secular center, secular centerright, secular right, Christian left, Christian center-left, Christian center, Christian centerright, Christian right, Personalist, Other, Unknown) for each country. Each series indicates the seat share in the lower house or constituent assembly held by secular left parties, secular center-left parties, etc. During years which are non-democratic, as defined by our democracy variable, all categories are scored as zero. In our analyses not only of social spending but also of inequality and poverty (Huber, Nielsen, Pribble and Stephens 2006; Huber, Pribble and Stephens 2006), we found that the religious dimension was not related to any of the dependent variables. Thus, we combined the religious and secular categories. Following Cusack and Fuchs (2002), we then calculated legislative partisan balance of power (or simply legislative partisan balance) by weighting the seat share in a given year of each category of parties by -1 for right, -0.5 for center-right, 0 for center, 0.5 for center-left, and 1 for left parties. For example in Costa Rica in 1971, the center right proportion of legislative seats was .386, the center left .579 and the left was .035 . The legislative partisan balance was $(.386 *-.5)+(.579 * .5)+(.035 * 1)=.132$. Finally, we cumulated the weighted value within each series from 1945 to the year of observation. We created a cumulated measure of executive partisan balance in the same way, based on which party controlled the presidency.

We measure federalism with a dichotomous variable. Brazil, Mexico, Argentina, and Venezuela were classified as federal, and the rest of the countries were classified as not federal. To test whether federalism only affected spending during periods of democracy, we created an interaction term in which the four federal countries were coded 
as 1 in years in which they were restricted or full democracies and all other observations were coded as zero.

Five variables comprise our measures of globalization. Trade openness is measured as exports and imports as a percentage of gross domestic product. Foreign direct investment measures net inflows of investment as a percentage of gross domestic product. We measure a central government's deficit by subtracting total expenditures from total revenues, as a percentage of gross domestic product. Finally, we use a dichotomy to measure whether or not a country has repurchase obligations to the IMF in a given year. To derive our independent variable for IMF influence, we then cumulate the dichotomy from 1970. We also included Morley et al.'s (1999) index of capital account liberalization, but it is only available for 362 of our 510 country years.

We employ three additional economic and demographic controls. First, we use real gross domestic product per capita, adjusted for purchasing power parities. Second, we include the percentage of the population which is 65 and older for the model predicting social security and welfare spending, and the percentage of the population which is under 15 years of age for the model predicting spending on health and education. Finally, we include an urbanization variable, which measures the percentage of the population that lives in areas defined as urban.

\section{Analytic Techniques}

We use an unbalanced panel data set with 446 observations from 18 Latin American countries. Table 2 lists the countries and the means of the dependent variables and the number of observations for each country. The data span the period 1970 to 2000 . With few exceptions, the observations are annual. Hicks (1994) notes that "errors for 
regression equations estimated from pooled data using OLS [ordinary least squares regression] procedures tend to be (1) temporally autoregressive, (2) cross-sectionally heteroskedastic, and (3) cross-sectionally correlated as well as (4) conceal unit and period effects and (5) reflect some causal heterogeneity across space, time, or both" (p.172). We follow Beck and Katz's (1995) recommended procedure, using panel-corrected standard errors, corrections for first-order auto-regression, and imposition of a common rho for all cross-sections. This procedure is implemented in version 8.0 of the Stata econometrics program. Since there is some trend in our data, we do not include a lagged dependent variable as recommended by Beck and Katz (1996) because in this situation the lagged dependent variable inappropriately suppresses the power of other independent variables, as Achen (2000) has shown. ${ }^{10}$ Beck and Katz (2004:16-17) have shown that correcting for first order auto-regression actually does include a lagged dependent variable on the right hand side of the equation. Thus, it does deal with the problem of serial correlation but without, as our results show, suppressing the power of other independent variables.

Beck and Katz (1996) and others have argued for the inclusion of country dummies in order to deal with omitted variable bias. Plümper et al. (2005: 330-34) in their recent treatment of this issue have countered that inclusion of country dummies does much more than eliminate omitted variable bias. It also (1) eliminates any variation in the dependent variable which is due to time invariant factors such as difference in constitutional structures, (2) greatly reduces the coefficients of factors that vary mainly between countries, (3) eliminates any differences in the dependent variable due to differences at $\mathrm{t} 1$ in the time series, and (4) "completely absorb(s) differences in the level 
of the independent variables across the units" (p.331, emphasis in the original).

Elaborating on this last point, they argue that if one hypothesizes that the level of the independent variable has an effect on the level of the dependent variables (e.g. history of democracy and level of social expenditures), "a fixed effects specification is not the model at hand. If a theory predicts level effects, one should not include unit dummies. In these cases, allowing for a mild bias resulting from omitted variables is less harmful than running a fixed effects specification.” (p. 334). We do hypothesize (\#1 above) effects of time invariant factors (federalism), (\#3) effects in the levels of our independent variables prior to $\mathrm{t} 1$ on the level of the dependent variable at $\mathrm{t}$, and (\#4) effects of levels of the independent variables on levels of the dependent variable. In addition, variation in several of our independent variables is primarily cross sectional (\#2). Thus, it is clear that fixed effects estimation or the inclusion of country dummies is not appropriate in this case.

To check our results for robustness, we reestimated all of the models with OLS estimation of the regression coefficients, which provides consistent estimates of the regression coefficients, and robust-cluster estimators of the standard errors. The robustcluster variance estimator is a variant of the Huber-White robust estimator that remains valid (i.e., provides correct coverage) in the presence of any pattern of correlations among errors within units, including serial correlation and correlation due to unit-specific components (Rogers 1993). Thus the robust-cluster standard errors are unaffected by the presence of unmeasured stable country-specific factors causing correlation among errors of observations for the same country, or for that matter any other form of within-unit error correlation. The robust-cluster estimator requires errors to be uncorrelated between 
clusters. The latter assumption might be violated if unmeasured factors affect the dependent variable in all units at the same point in time. Global economic fluctuations, such as the debt crisis period in Latin America, could produce such contemporaneous effects. To evaluate the potential impact of such unmeasured period specific factors we re-estimated the models with indicator variables for the debt crisis (1982-89) and for the 1990s (1990-2000); the baseline category corresponds to 1970-81. The robust cluster OLS estimations were substantially the same as the Prais Winsten estimations. We note below instances in which the robust cluster estimations indicate that our significant results are not robust.

Since the models in Tables 3 and 4 are GLS regressions, there is no conventional $\mathrm{R}^{2}$. The measure calculated by the Stata program to measure goodness of fits is a GLS "pseudo $\mathrm{R}^{21}$. Given the sensitivity of this statistic to the assumptions made in order to calculate them, some analysts consider the OLS $\mathrm{R}^{2}$ to be a better indicator of goodness of fit. We report both $\mathrm{R}^{2} \mathrm{~s}$.

\section{Results}

The results of regressions of social security and welfare spending on the independent variables are displayed in Table 3. Model 1 includes the control variables. Model 2 adds the political variables. Model 3 substitutes executive partisan balance for legislative partisan balance. Democracy is the only political variable that is significant and correctly signed. A move from the $10^{\text {th }}$ percentile to the $90^{\text {th }}$ percentile on democracy (a move of 29.5 years) results in an increase in social security spending of $1.8 \%$ of GDP. While not very large, this effect is not negligible, given a sample mean of $3.6 \%$ of GDP. Repressive authoritarianism falls short of significance. Both executive 
and legislative partisan balance are negative indicating that right-of-center legislatures and governments actually tend to spend more (or cut less) but both coefficients are insignificant. ${ }^{11}$ Federalism and the democracy-federalism interaction term are not significant. The one control variable which is consistently significant, aged population, is a very powerful determinant of the level of spending on social security and welfare. A move from the $10^{\text {th }}$ percentile to the $90^{\text {th }}$ percentile on the percentage of the aged population (a move of 5.5\%) results in an increase in social security and welfare spending of $6.5 \%$ of GDP. In light of the sample mean of $3.6 \%$ of GDP, this is a very large effect. Indeed, the zero order correlation between the social security and welfare spending and aged percentage of the population is .79 .

The results of regressions of health and education spending on the independent variables are displayed in Table 4. The models contain the same independent variables as in Table 3 except that youth population is substituted for aged population. Democracy and repressive authoritarianism are correctly signed and significant. A move from the $10^{\text {th }}$ percentile to the $90^{\text {th }}$ percentile on repressive authoritarianism ( 5 years) results in a decrease in health and education spending of $1.3 \%$ of GDP; a similar change in democracy results in an increase in spending of $2.7 \%$ of GDP. In light of a sample mean of $5.6 \%$ of GDP, this a substantively large effect. ${ }^{12}$ Federalism and the democracy federalism interaction term are not significant. Both legislative and executive partisanship are incorrectly signed and the latter is significant. However, it is not significant in the robust cluster estimates, indicating that the finding is not robust.

GDP per capita is consistently significant and correctly signed, but its effect is modest: A move from the $10^{\text {th }}$ percentile to the $90^{\text {th }}$ percentile is associated with an 
increase in health and education spending of $1.4 \%$ of GDP. Government budget deficit is also significant and correctly signed. A move from the $10^{\text {th }}$ to $90^{\text {th }}$ percentile on this variable results in a decrease of $0.3 \%$ of GDP in health and education spending, a surprisingly small effect. ${ }^{13}$

In contrast to the results for social security and welfare spending, the debt crisis indicator is significant and negative. All countries experienced pressures to reduce expenditures across the board in this period. However, social security and welfare expenditures were more resilient than health and education expenditures.

\section{Discussion and Conclusions}

Our main findings of theoretical interest are that regime forms are important determinants of the amount governments spend on transfers and social services. Democracy matters in the long run for both social security and welfare, and health and education spending. These findings suggest that democratic governments of all political stripes are more responsive to demands for state provision of social security and welfare, and for health and education services than are authoritarian governments. Highly repressive authoritarian regimes keep spending on health and education low. Interestingly, they do not have a similar effect on social security and welfare spending.

Partisanship does not matter for the overall amount of social expenditures. The difference between governments of varying political colors is apparently not in how much they spend, but in how they allocate what they spend. We have qualitative evidence that left-of-center parties have favored programs with progressive profiles, such as non-contributory and conditional transfer programs and school feeding programs and preventive health care (e.g. the Unidad Popular in Chile, the PT in Brazil, the FA in 
Uruguay), and we know from quantitative studies that a left-leaning balance of power in legislatures is associated with lower inequality (Huber, Nielsen, Pribble and Stephens 2006), which leads us to infer that left governments find it difficult to increase the overall amount of social expenditures but are more successful in shaping expenditure patterns. ${ }^{14}$

Our data do not allow us consistently to separate out progressive from regressive kinds of expenditures. For the restricted set of observations for which the IMF provided figures for social security separately from welfare expenditures (120 observations for 13 countries, virtually exclusively for the period 1972-82) the results of our analyses showed the expected pattern of partisanship. Democracy remained positive and significant for both kinds of expenditures. The legislative partisan balance was negative for the combined measure (which is dominated by social security spending) and for social security spending alone, and both effects were significant, and it was positive for welfare spending, but not significant.

From many studies done by international organizations (cited above) we know that most social security schemes in Latin America at the beginning of the $21^{\text {st }}$ century are highly regressive. Left of center governments were hardly in power long enough during the formative years of the social security schemes to shape them into redistributive instruments originally. In the 26 years from 1945 to 1970 , our data show only one country, Uruguay, where parties of the left and center left together held an average of slightly more than $50 \%$ of seats (a score of 14 , with 13 constituting the $50 \%$ mark). In Venezuela and Costa Rica, they averaged about $40 \%$, and in Chile about $30 \% .{ }^{15}$ Once the social security schemes were established, they created entitlements, and it became 
very difficult for left of center governments to reallocate resources from privileged to the general social security schemes or from social security to welfare expenditures.

Unfortunately, there are no conclusive studies of the distributive impact of social security schemes as of the late 1970s, before the onset of the debt crisis. It is safe to assume that they were less regressive at that point in time in countries with strong import substitution industrialization, particularly Argentina and Uruguay where the formal sector was large and unemployment was very low. In the wake of the debt crisis and structural adjustment, the size of the informal sector grew significantly, which made the social security schemes more regressive everywhere. In that situation, left-leaning governments were held back by economic constraints in their efforts to increase expenditures to improve and expand the general schemes to cover the growing informal sector.

There is further evidence for the high resilience of social security expenditures. Neither the indicator for the debt crisis nor government deficits depressed social security expenditures, whereas they both had significant negative effects on health and education spending. The same is true for highly repressive authoritarian regimes; they were generally reluctant to make major cuts in social security schemes but not so in health and education expenditures.

Our analysis shows that for social security and welfare spending, demographics are crucial. Once the social security schemes are put into place, they create entitlements that are difficult to change, and expenditures grow with the growth of entitled groups. The most plausible explanation is the political cost of cutting entitlements, but the legal anchoring of social security schemes arguably contributes to their resilience. Other rights are legally anchored as well - prominently among them the right to public education and 
health care - but they do not carry the same quality of personal entitlement. Moreover, declines in quality of education and health services are not experienced as immediately and starkly as declines in social security benefits. Since social security schemes primarily benefit the more privileged and more organized groups, cuts would affect the more politically articulate and influential. The examples of Uruguay and Argentina show the potential of large-scale pensioner mobilization in defense of their entitlements very clearly.

Spending on health and education is more susceptible to economic and political constraints and opportunities than spending on social security. Again, a long record of democracy drives up health and education spending, and the effect is stronger than for social security and welfare spending. Since we know that significant sectors of the middle and upper classes have opted out of the public systems and that on average overall patterns of health and education spending were slightly progressive by the late 1990s, we can attribute the relationship between democracy and spending to the opportunities that democracy opens for the self-organization of the underprivileged and their capacity to push for better health and education services. Highly repressive authoritarian regimes generally crush lower class organizations and thus their ability to push for expansion or resist curtailments of health and education services. The fact that highly repressive regimes keep spending on health and education low but not on social security can in part be explained by these regimes' predisposition to target physical, legal, and economic repression at the lower classes and blue-collar unions, the main users of public health and education services, and their reluctance to take on middle and upper middle classes, the disproportionate beneficiaries of social security schemes. In part it can also be explained 
by the probability of a stronger reaction across the board against cuts in social security than against declines in the quality of health and education services, and the possibility of a broad opposition coalition formation.

The stronger impact of economic factors on health and education spending than on social security and welfare spending is underlined by the positive effect of GDP per capita on the former and the lack of such an effect on the latter. The fact that more affluent countries devote a greater share of resources to health and education may mean that greater availability of resources facilitates devoting a greater share to these purposes, or it may mean that countries with better supported health and education systems have a stronger human capital base and thus are more successful economically. Budget deficits and the debt crisis also had a constraining effect on health and education expenditures, in contrast to their effect on social security expenditures.

As noted, the previous studies of social expenditure in Latin America are not really comparable to ours, because they are studies of change and not levels of expenditures and only Kaufman and Segura (2001) include a measure of political power distributions, the political orientation of presidents. However, their study is frequently cited, which calls for a brief discussion. There are three differences between Kaufman and Segura's and our own coding. They coded political orientation of presidents regardless of whether the president was democratically elected or not, ${ }^{16}$ and we coded the political orientation of parties represented in parliament, as well as of presidents, only during democratic periods. Second, they used a dichotomous coding of popularly oriented/ popularly based or not, whereas we used a left/ center/ right coding, as explained above. Third, they coded the orientation on the basis of the founding coalition 
or constituency of the party and continued to code parties the same way for their whole history, whereas we followed the conventional coding in OECD studies and Coppedge's coding that allow for changes in classification on the left-right scale if parties change their basic orientation towards their original constituency and priorities of growth and redistribution.

Kaufman and Segura find that change towards populist presidents (but not incumbency the year before) is positively associated with change in social security and welfare spending and negatively associated with change in health and education spending. They interpret this as attempts by populist presidents to protect pension spending at the expense of investment in human capital (2001: 580). This interpretation is compatible with our interpretation that health and education spending is more vulnerable than social security and welfare spending. They further find that both democracy the year before the observation and change towards democracy is negatively associated with change in spending on social security and welfare, and democracy the year before is positively associated with change in spending on health and education as a percentage of GDP. The latter finding is compatible with ours.

Our results contrast starkly with those of studies of welfare states in OECD countries, where partisanship has figured prominently. In addition to the structural and historical differences to which we will return momentarily, we can point to differences in the time periods covered by these studies to help explain this contrast. Studies of OECD countries typically include the Golden Age of post-war capitalism, the period between World War II and the first oil shocks, along with the period of slowed growth, globalization, and fiscal pressures on the welfare state beginning in the 1980s. There is 
some disagreement over whether partisan effects disappeared in the latter phase or whether they persist, but there is agreement that they have weakened under the political constraints of entitlements and economic constraints on expenditure increases. Due to data availability, our study of Latin American countries can only cover the period since the 1970s, that is, a period of significant fiscal constraints resulting from slowed economic growth, the debt crisis of the 1980s and the volatility of the 1990s. These constraints can help to explain the absence of partisan effects.

The major reasons for the weakness of partisan effects, though, are structural and historical in nature. As noted, parties of the left were generally too weak to shape social security systems in their formative period, which in turn can be linked to the weakness of the record of democracy itself. Parties of the democratic left and center tended to suffer from prohibition and even persecution during many authoritarian periods, as did their support groups in civil society, prominently among them labor unions. Thus, they entered democratic periods as relatively weak actors. A comparison with Western European left of center parties, with their close links to civil society organizations and policy think tanks, illustrates this weakness well. As the democratic record gets longer, and if leftleaning parties along with other democratic institutions manage to consolidate, we should expect stronger political effects on social policy also, particularly if the region experiences greater economic stability and growth than over the past 25 years.

If we keep in mind that a left-leaning partisan balance does depress inequality over the longer run, the absence of partisan effects on the level of spending suggests that 
left-of-center parties have found it difficult to raise new revenue in an economic environment where both financial and human capital are highly concentrated, highly mobile, and politically influential, and that these parties instead push to change the structure of spending to make it more progressive. They also seek legal and regulatory changes to promote the interests of the underprivileged. In the best of all cases, longer records of democracy will be accompanied by a strengthening of political parties, particularly those representing the underprivileged and committed to redistributive social policy and investment in human capital, which could put in motion a virtuous cycle among democracy, human capital, economic development, and human welfare. 
${ }^{1}$ It is important to point out that social security systems have been regressive for three reasons. First, there typically were/are different programs for different categories of employees (blue collar, white collar, civil servants) and sectors (e.g. military, judges, university professors, bank employees) with different levels of generosity of benefits, with the more generous ones being subsidized by general taxes. Second, within each scheme benefits tend to be earnings-related. Third, social security coverage for the most part has been tied to formal sector employment. Since the main constituencies of left parties have been blue collar workers and the poor, or people in the informal sector, left parties have promoted reforms to unify programs and equalize benefits, and to include people in the informal sector by expanding non-contributory social transfers and health care programs. Good examples of this are the left of center parties in Chile (going back to the Unidad Popular), Uruguay, and Costa Rica.

${ }^{2}$ The IMF sources report the two types of expenditures separately for 179 country years only; in these observations, social security accounts for $83 \%$ of the spending.

3 We also examined measures developed by Alvarez et al., Freedom House, and Mainwaring et al. Not surprisingly all of these are highly correlated, particularly our cumulative versions of the measures. Alvarez et al. ends in 1990 and Freedom House begins in 1972, so these measures do not have sufficient coverage for our purposes. The Mainwaring et al. and Rueschemeyer et al. annual measures are highly correlated (.85) and the cumulative versions of the measures are very highly correlated (.95). Thus, it is not surprising that substituting Mainwaring for Rueschemeyer yielded the same results. 
${ }^{4}$ For the three political variables we developed, and experimented with, measures cumulated over four periods: 1945 to year of observation, and the 15, 10, and 5 years preceding the year of observation. We selected the measure used in the final analyses for theoretical reasons (democratic history expected to have longer term effect) as well as empirical ones (better performance in regression models).

${ }^{5}$ For a general defense of the validity of expert surveys in assessing party positions, see Steenbergen, Hooghe, and Marks (forthcoming).

${ }^{6}$ See Coppedge (1997) for detailed category descriptions; available at http://www.nd.edu/ mcoppedg/crd/criteria.htm..

${ }^{7}$ Using Coppedge's coding of the Peronists did not change the results of the analysis. ${ }^{8}$ Unlike Coppedge (1997), we did not use expert surveys. Instead, two members of our team independently consulted numerous primary and reference materials in order to code each political party. Then, on parties for which there was a disagreement, we did seek external expert input, and finally the entire research team convened to make a decision. ${ }^{9}$ Our procedure of tallying seat shares differs from Coppedge (1997), who tallied vote shares. We make this choice on the grounds that seat shares are more consequential for policy than vote shares.

${ }^{10}$ In these data, the lagged dependent variable explains $98 \%$ of the variation in the dependent variable.

${ }^{11}$ Running the models with different time periods for the political variables does not change the results. All periods for partisan balance and repressive authoritarianism remain insignificant; the results for democracy for 15 previous years are somewhat stronger but for 5 and 10 years are insignificant. 
${ }^{12}$ Running the models with different time periods for the political variables does not change the results for repressive authoritarianism, which remains significant but somewhat weaker for the longer periods, and partisan balance, which remains insignificant. Democracy, however, falls short of significance for the 10 and 5 year periods, but is significant for the 15 year period. This consistent pattern supports our theoretical contention that it is long-term democratic rule that matters for policy. ${ }^{13}$ Regressions with the Morley at el. (1999) capital account liberalization index for both dependent variables caused us to lose 148 cases, and the index was not significant, so we are not including the models in the tables.

14 The pattern of social expenditures is not the only factor shaping income distribution, of course. Left governments have also made use of other policies to protect lower income groups, such as improvements in labor legislation and the minimum wage.

${ }^{15}$ Keep in mind that parties only receive scores for democratic periods; in nondemocratic periods, we obviously would not expect left parties to influence social policy formation.

16 Thus, their analysis, which begins in 1973, includes the military presidencies of 197375 in Peru and of 1973-79 in Ecuador, and all Mexican presidents since 1973. 


\section{References}

Achen, Christopher. 2000. "Why Lagged Dependent Variables Can Suppress the Explanatory Power of Other Independent Variables.” Paper presented at the Annual Meeting of the Society for Political Methodology, UCLA. (July).

Alcántara Sáez, Manuel and Flavia Freidenberg . (eds.) 2001. Partidos políticos de América Latina. Salamanca, Spain: Ediciones Universidad de Salamanca.

Alcántara Sáez, Manuel and Cristina Rivas. 2006. "The Left-Right Dimension in Latin American Party Politics.” Paper presented at the Annual Meeting of the American Political Science Association.

Ameringer, Charles D. 1992. (ed.) Political Parties of the Americas, 1980s to 1990s. London.

Ames, Barry. 1995. "Electoral Rules, Constituency Pressures, and Pork Barrel: Bases of Voting in the Brazilian Congress." The Journal of Politics. 57. 2 (May): 324-43.

Avelino, George, David S. Brown, and Wendy Hunter. 2005. "The Effects of Capital Mobility, Trade Openness, and Democracy on Social Spending in Latin America, 1980-1999.” American Journal of Political Science, Vol. 49, No. 3 (July): 625-641.

Beck, Nathaniel and Jonathan N. Katz. 2004. "Time-Series-Cross-Section Issues: Dynamics, 2004." Paper delivered at the Annual Meeting of the Society for Political Methodology, Palo Alto, Stanford University. 
Beck, Nathaniel and Jonathan N. Katz. 1995. "What to do (and Not to Do) with Time-Series-Cross-Section Data in Comparative Politics." American Political Science Review 89 (3):634-647.

Beck, Nathaniel and Jonathan N. Katz. 1996. "Nuisance vs. Substance: Specifying and Estimating Time-Series-Cross-Section Models." Political Analysis 8, 1-36.

Bonoli, Giuliano and André Mach. 2000. "Switzerland: Adjustment Politics with Institutional Constraints." In Fritz Scharpf Scharpf and Vivien A. Schmidt (eds.) Welfare and Work in the Open Economy. Volume II. Diverse Responses to Common Challenges. Oxford: Oxford University Press.

Bradley, David, Evelyne Huber, Stephanie Moller, François Nielsen, and John Stephens. 2003. "Distribution and Redistribution in Post-industrial Democracies." World Politics. Vol. 55, No. 2 (January) 193-228.

Brown, David, and Wendy Hunter. 1999. "Democracy and Social Spending in Latin America, 1980-92.” American Political Science Review 93: 779-90.

Brown, David, and Wendy Hunter. 2004. "Democracy and Human Capital Formation: Education Spending in Latin America, 1980-1997." Comparative Political Studies (September) 37: 7, 842-864.

Castles, Francis. 1999. "Decentralization and the Post-war Political Economy." European Journal of Political Research 36.1: 27-53.

Castles, Francis. 1982. (ed.) The Impact of Parties. Beverly Hills, California: Sage. 
Castles, Francis and Peter Mair. 1984. "Left-Right Political Scales: Some 'Expert' Judgments." European Journal of Political Research 12: 73-88.

Colomer, Josep M. and Luis E. Escatel. 2004. "The Left-Right Dimension in Latin America.” Mexico City: CIDE, Centro de Investigación y Docencia Económicas. Working Papers, SDTEP 165.

Cominetti, Rossella. 1996. "Social Expenditure in Latin America: An Update.” Santiago, Chile: CEPAL Technical Department.

Coppedge, Michael. 1997. “A Classification of Latin American Political Parties.” Working Paper Series \#244. The Helen Kellogg Institute for International Studies, University of Notre Dame.

Cusack, Thomas R. and Susanne Fuchs. 2002.'Documentation Notes for Parties, Governments, and Legislatures Data Set.” Wissenschaftszentrum Berlin fuer Sozialforschung.

De Ferranti, David, Guillermo E. Perry, Fancisco H.G. Ferreira, and Michael Walton. 2004. Inequality in Latin America: Breaking with History? Washington, D.C.: The World Bank.

ECLAC. 2004. Social Panorama of Latin America. Santiago, Chile: United Nations Economic Commission for Latin America and the Caribbean. 2002. Social Panorama of Latin America. Santiago, Chile: United Nations Economic Commission for Latin America and the Caribbean. 1998. The Fiscal Covenant: Strengths, Weaknesses, Challenges. Santiago: United Nations Economic Commission for Latin America and the Caribbean. 
Gibson, Edward. L. 1997. “The Populist Road to Market Reform: Policy and Electoral Coalitions in Argentina and Mexico.” World Politics 49 (April).

Heston, Alan, Robert Summers, and Bettina Aten. Penn World Table Version 6.1, Center for International Comparisons at the University of Pennsylvania.

Hicks, Alexander. 1994. “Introduction to Pooling.” In Alexander Hicks \& Thomas Janoski (eds.). The Comparative Political Economy of the Welfare State (pp. 169-88). New York: Cambridge University Press.

Hicks, Alexander. 1999. Social Democracy and Welfare Capitalism: A Century of Income Security Policies. Ithaca, NY: Cornell University Press.

Hicks, Alexander and Joya Misra. 1993. "Political Resources and the Growth of Welfare in Affluent Capitalist Democracies, 1960-82." American Journal of Sociology 99: 668-710.

Huber, Evelyne, Charles Ragin, John D. Stephens. 1993. "Social Democracy, Christian Democracy, Constitutional Structure and the Welfare State." American Journal of Sociology 99: 711-49.

Huber, Evelyne, and John D. Stephens. 2001 Development and Crisis of the Welfare State: Parties and Policies in Global Markets. Chicago: University of Chicago Press.

Huber, Evelyne, Jenny Pribble, and John D. Stephens. 2006. "The Politics of Poverty in Latin America and the Caribbean." Paper delivered at the Meetings of the Latin American Studies Association, San Juan, Puerto Rico, March 15-18, 2006. 
Huber, Evelyne, Francois Nielsen, Jenny Pribble, and John D. Stephens. 2006. "Politics and Inequality in Latin America and the Caribbean." American Sociological Review, Vol. 71, No. 6 (December) 943-63.

International Monetary Fund. Various Years. Government Finance Statistics Yearbook. Washington: IMF.

International Monetary Fund. Various Years. International Financial Statistics Yearbook. Washington: IMF.

International Monetary Fund. 1986. “A Manual on Government Finance Statistics." Washington: IMF.

Kaufman, Robert R. and Alex Segura-Ubiergo. 2001. "Globalization, Domestic Politics, and Social Spending in Latin America.” World Politics, 53, 4 (July): 553-88.

Lijphart, Arend. 1981. "Political Parties: Ideologies and Programs." In David Butler, Howard R. Penniman, and Austin Ranney (eds.) Democracy at the Pools: A Comparative Study of Competitive National Elections. Washington, DC: American Enterprise Institute for Public Policy Research.

Lindert, Kathy, Emmanuel Skoufias, and Joseph Shapiro. 2005. "Redistributing Income to the Poor and the Rich: Public Transfers in Latin America and the Caribbean.” Discussion Draft. World Bank, October 24, 2005.

Luna, Juan P. and Elizabeth J. Zechmeister. 2005. "Political Representation in Latin America: A Study of Elite-Mass Congruence in Nine Countries." Comparative Political Studies, 38, 4 (May): 388-416.. 
Mainwaring, Scott and Timothy R. Scully. (eds.) 2003. Christian Democracy in Latin America: Electoral Competition and Regime Conflicts. Stanford, CA: Stanford University Press.

Mainwaring, Scott and Mariano Torcal. 2006. "Party System Institutionalization and Party System Theory After the Third Wave of Democratization." In Richard S. Katz and William Crotty (eds.) Handbook of Party Politics. Thousand Oaks: Sage Publications. 204-227.

Maioni, Antonia. 1998. Explaining Differences in Welfare State Development: A Comparative Study of Health Insurance in Canada and the United States. Princeton, NJ: Princeton University Press.

Mesa-Lago, Carmelo. 1978. Social Security in Latin America: Pressure Groups, Stratification, and Inequality. Pittsburgh: University of Pittsburgh Press.

Mesa-Lago, Carmelo. 1989. Ascent to Bankruptcy: Financing Social Security in Latin America. Pittsburgh: University of Pittsburgh Press.

Morley, Samuel and D. Coady. 2003. From Social Assistance to Social Development: A Review of Targeted Education Subsidies in Developing Countries. Washington, DC: International Food Policy Research Institute.

Morley, Samuel, Roberto Machado and Stefano Pettinato. 1999. "Indexes of Structural Reform in Latin America.” ECLAC Serie Reformas Económicas 12.

Muller, Katharina. 2005. "Sozialpolitik in Lateinamerika: Aktuelle Problemlagen, neuere Entwicklungen und verbleibende Herausforderungen.” In 
Dirk Messner and Imme Scholz (eds.) Zukunftsfragen der Entwicklungspolitik. Baden-Baden, Germany: Nomos Verlagsgesellschaft. 199-219.

Murillo, Victoria M. 2001. Labor Unions, Partisan Coalitions and Market Reforms in Latin America. Cambridge: Cambridge University Press.

Obinger, Herbert, Stephan Leibfried and Francis G. Castles. 2005. "Introduction: Federalism and the Welfare State.” In Herbert Obinger, Stephan Leibfried and Francis G. Castles (eds.) Federalism and the Welfare State: New World and European Experiences. Cambridge: Cambridge University Press.

Pluemper, T., V. E. Troeger, and Philip Manow. 2005. "Panel Data Analysis in Comparative Politics: Linking Method to Theory." European Journal of Political Research 44: 327-54.

Rogers, William H. 1993. "Regression Standard Errors in Clustered Samples." Stata Technical Bulletin 13: 19-23. Reprinted in Stata Technical Bulletin Reprints 3: 88-94.

Rueschemeyer, Dietrich, Evelyne Huber Stephens and John Stephens. 1992. Capitalist Development and Democracy. Chicago: University of Chicago Press.

Schmidt, Manfred G. 1997. "Determinants of Social Expenditure in Liberal Democracies; The Post World War II Experience.” Acta Politica 32, 2: $153-73$. 
Scott, John. 2003. "Public Spending and Inequality of Opportunities in Mexico: 1970-2000.” In Quentin Wodon (ed.) “Public Spending, Poverty, and Inequality in Latin America.” World Bank, Washington DC. Processed. Cited in deFerranti et al. 2004.

Steenbergen, Marco, Liesbet Hooghe, Gary Marks. "Evaluating Expert Judgements." Forthcoming in European Journal of Political Research.

Swank, Duane. 2002. Global Capital, Political Institutions, and Policy Change in Developed Welfare States. New York: Cambridge University Press. 1992. "Politics and the Structural Dependence of the State in Democratic Capitalism.” American Political Science Review 86: 38-54.

Van Kersbergen, Kees. 1995. Social Capitalism: A Study of Christian Democracy and the Welfare State. London and New York: Routledge.

Wibbels, Erik. 2006. "Dependency Revisited: International Markets, Business Cycles, and Social Spending in the Developing World." International Organization 60 (Spring) 433-468.

Wodon, Quentin (ed.) 2003. "Public Spending, Poverty, and Inequality in Latin America." World Bank, Washington DC. Processed. Cited in deFerranti et al. 2004.

World Bank. World Development Indicators 2003. 


\section{Table 1. Variable Descriptions, Data Sources and Hypothesized Effects for Social Spending Levels in Latin America}

\begin{tabular}{|c|c|c|c|}
\hline \multirow[b]{2}{*}{ Variable } & \multirow[b]{2}{*}{ Description } & \multicolumn{2}{|c|}{ Hypothesized impact: } \\
\hline & & $\begin{array}{l}\text { Social Security } \\
\text { \& welfare }\end{array}$ & $\begin{array}{l}\text { Health \& } \\
\text { education }\end{array}$ \\
\hline \multicolumn{4}{|l|}{ Dependent Variables } \\
\hline Social security \& welfare spending & Social security and welfare spending as a percent of GDP. ${ }^{a}$ & & \\
\hline Health \& education spending & Health and education spending as a percent of GDP.a & & \\
\hline \multicolumn{4}{|l|}{ Independent Variables } \\
\hline \multicolumn{4}{|l|}{ Methodological controls } \\
\hline Data source indicator & Coded 1 if Cominetti (1996) is the source for health and spending data, otherwise coded $0 .^{\text {a }}$ & $+/-$ & $+/-$ \\
\hline Debt crisis & 1982-1989 & - & - \\
\hline Recovery & $1990-2000$ & $+/-$ & $+/-$ \\
\hline \multicolumn{4}{|l|}{ Logic of industrialism } \\
\hline GDP per capita & Per capita GDP in thousands of 1995 purchasing power parity dollars. ${ }^{b}$ & + & + \\
\hline Urban population & $\%$ of population living in areas defined as urban. ${ }^{c}$ & + & + \\
\hline Aged population & $\%$ of population age 65 and older. ${ }^{c}$ & + & \\
\hline Youth population & $\%$ of population age 14 and younger. ${ }^{c}$ & & + \\
\hline \multicolumn{4}{|l|}{ Globalization } \\
\hline Trade openness & Total exports and imports as a percent of GDP. ${ }^{b}$ & $+/-$ & $+/-$ \\
\hline Foreign direct investment inflows & Net inflows of foreign direct investment as a percent of GDP. ${ }^{c}$ & - & + \\
\hline Deficit & Government deficit as a percentage of GDP. ${ }^{c}$ & - & - \\
\hline IMF & $\begin{array}{l}\text { Scored } 1 \text { for each year a country has repurchase obligations with the IMF and } 0 \text { for each year it } \\
\text { does not, cumulative since } 19700^{c}\end{array}$ & - & - \\
\hline \multicolumn{4}{|l|}{ Political factors } \\
\hline Democracy & Cumulative years of democracy from 1945 to the year of the observation. ${ }^{a}$ & + & + \\
\hline Federalism & Argentina, Brazil, Mexico, and Venezuela coded as federal. ${ }^{a}$ & $+/-$ & $+/-$ \\
\hline Democratic federalism & Dichotomous indicators of federal democracies. ${ }^{a}$ & $+/-$ & $+/-$ \\
\hline Repressive authoritarianism & Years of repressive authoritarianism in the previous 5 years. ${ }^{a}$ & - & - \\
\hline Legislative Partisan Balance & $\begin{array}{l}\text { Cumulative index of ideological center of gravity in the lower house from } 1945 \text { to the year of } \\
\text { the observation (see text). }{ }^{\text {a }}\end{array}$ & $+/-$ & + \\
\hline Executive Partisan Balance & $\begin{array}{l}\text { Cumulative index of ideological center of gravity in the executive from } 1945 \text { to the year of the } \\
\text { observation (see text). }{ }^{\text {a }}\end{array}$ & $+/-$ & + \\
\hline
\end{tabular}

Sources: a (author cite); ${ }^{\mathrm{b}}$ Penn World Table Version $6.1 ;{ }^{\mathrm{c}}$ World Bank (2003) 
Table 2: Mean Social Spending as a Percentage of GDP

\begin{tabular}{lccc} 
& $\begin{array}{c}\text { Social Security } \\
\text { and Welfare }\end{array}$ & $\begin{array}{c}\text { Health and } \\
\text { Education }\end{array}$ & $\mathrm{N}$ \\
\hline Argentina & 5.5 & 5.4 & 30 \\
Bolivia & 2.9 & 6.0 & 21 \\
Brazil & 7.4 & 4.5 & 27 \\
Chile & 8.7 & 5.9 & 29 \\
Colombia & 1.8 & 5.6 & 11 \\
Costa Rica & 3.7 & 9.5 & 29 \\
Dominican Republic & 0.9 & 3.5 & 28 \\
Ecuador & 0.2 & 4.6 & 18 \\
El Salvador & 0.5 & 3.7 & 31 \\
Guatemala & 0.6 & 2.6 & 27 \\
Honduras & 0.7 & 6.0 & 24 \\
Mexico & 2.9 & 5.5 & 27 \\
Nicaragua & 3.0 & 5.8 & 15 \\
Panama & 4.5 & 10.0 & 21 \\
Paraguay & 2.2 & 2.5 & 27 \\
Peru & 0.9 & 3.8 & 23 \\
Uruguay & 13.7 & 5.0 & 28 \\
Venezuela & 1.8 & 5.4 & 30 \\
\hline All country years & 3.6 & 5.2 & 446 \\
10th percentile & 0.4 & 2.4 & \\
90th percentile & 8.5 & 9.3 &
\end{tabular}


Table 3: Prais-Winsten Estimates of Determinants of Social Security and Welfare Spending

\begin{tabular}{|c|c|c|c|}
\hline$\overline{\text { Variables }}$ & Model 1 & 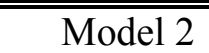 & 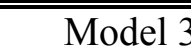 \\
\hline \multirow[t]{2}{*}{ Debt crisis (1982-89) } & .266 & .172 & .209 \\
\hline & $(.227)$ & $(.228)$ & $(.228)$ \\
\hline \multirow[t]{2}{*}{ Recovery (1990-2000) } & .370 & .205 & .278 \\
\hline & $(.332)$ & $(.337)$ & $(.334)$ \\
\hline \multirow[t]{2}{*}{ GDP per capita } & -.102 & -.171 & -.162 \\
\hline & $(.164)$ & $(.167)$ & $(.170)$ \\
\hline \multirow[t]{2}{*}{ Urban population } & $.050 *$ & .033 & .032 \\
\hline & $(.023)$ & $(.030)$ & $(.032)$ \\
\hline \multirow[t]{2}{*}{ Aged population } & $1.283 *$ & $1.196 *$ & $1.205 *$ \\
\hline & $(.298)$ & $(.238)$ & $(.255)$ \\
\hline \multirow[t]{2}{*}{ Trade openness } & -.008 & -.007 & -.008 \\
\hline & $(.006)$ & $(.006)$ & $(.006)$ \\
\hline \multirow[t]{2}{*}{ FDI } & .002 & -.001 & .000 \\
\hline & $(.021)$ & $(.218)$ & $(.021)$ \\
\hline \multirow[t]{2}{*}{ Deficit } & -.007 & -.011 & -.010 \\
\hline & $(.016)$ & $(.016)$ & $(.016)$ \\
\hline \multirow[t]{2}{*}{ IMF } & -.025 & -.012 & -.017 \\
\hline & $(.036)$ & $(.036)$ & $(.038)$ \\
\hline \multirow[t]{2}{*}{ Democracy } & & $.061 *$ & $.054 *$ \\
\hline & & $(.031)$ & $(.032)$ \\
\hline \multirow[t]{2}{*}{ Federalism } & & .746 & .775 \\
\hline & & $(.951)$ & $(1.017)$ \\
\hline \multirow{2}{*}{ Democratic federalism } & & .072 & .077 \\
\hline & & $(.370)$ & $(.373)$ \\
\hline \multirow[t]{2}{*}{ Repressive authoritarianism } & & .124 & .104 \\
\hline & & $(.139)$ & $(.145)$ \\
\hline \multirow[t]{2}{*}{ Legislative partisan balance } & & -.090 & \\
\hline & & $(.052)$ & \\
\hline \multirow[t]{2}{*}{ Executive partisan balance } & & & -.026 \\
\hline & & & $(.037)$ \\
\hline Common $\rho$ & .91 & .88 & .89 \\
\hline \multirow[t]{2}{*}{ Constant } & $-4.354 *$ & $-3.835 *$ & $-3.641 *$ \\
\hline & $(1.269)$ & $(1.507)$ & $(1.593)$ \\
\hline OLS R $^{2}$ & $.68 *$ & $.73 *$ & $.72 *$ \\
\hline Prais Winsten $\mathrm{R}^{2}$ & $.24 *$ & $.31 *$ & $.29 *$ \\
\hline
\end{tabular}


Table 4: Prais-Winsten Estimates of Determinants of Health and Education Spending

\begin{tabular}{|c|c|c|c|}
\hline Variables & Model 1 & Model 2 & Model 3 \\
\hline \multirow[t]{2}{*}{$\begin{array}{l}\text { Debt crisis (1982-89) } \\
\end{array}$} & $-.406 *$ & $-.439 *$ & $-.462 *$ \\
\hline & $(.217)$ & $(.207)$ & $(.206)$ \\
\hline \multirow[t]{2}{*}{ Recovery (1990-2000) } & -.225 & -.460 & -.497 \\
\hline & $(.316)$ & $(.298)$ & $(.294)$ \\
\hline \multirow[t]{2}{*}{ Data source indicator } & $.994 *$ & $1.076 *$ & $1.055 *$ \\
\hline & $(.312)$ & $(.333)$ & $(.329)$ \\
\hline \multirow[t]{2}{*}{ GDP per capita } & $.231 *$ & $.236 *$ & $.200 *$ \\
\hline & $(.109)$ & $(.100)$ & $(.099)$ \\
\hline \multirow[t]{2}{*}{ Urban population } & -.002 & -.019 & -.010 \\
\hline & $(.023)$ & $(.023)$ & $(.023)$ \\
\hline \multirow[t]{2}{*}{ Youth population } & .032 & .101 & $.122 *$ \\
\hline & $(.066)$ & $(.067)$ & $(.068)$ \\
\hline \multirow[t]{2}{*}{ Trade openness } & .002 & .006 & .003 \\
\hline & $(.006)$ & $(.006)$ & $(.006)$ \\
\hline \multirow[t]{2}{*}{ FDI } & -.250 & -.024 & -.024 \\
\hline & $(.028)$ & $(.031)$ & $(.030)$ \\
\hline \multirow[t]{2}{*}{ Deficit } & $-.041 *$ & $-.039 *$ & $-.040 *$ \\
\hline & $(.015)$ & $(.015)$ & $(.015)$ \\
\hline \multirow[t]{2}{*}{ IMF } & $.147^{\wedge}$ & $.121^{\wedge}$ & $.135^{\wedge}$ \\
\hline & $(.035)$ & $(.030)$ & $(.032)$ \\
\hline \multirow[t]{2}{*}{ Democracy } & & $.090 *$ & $.085 *$ \\
\hline & & $(.026)$ & $(.025)$ \\
\hline \multirow[t]{2}{*}{ Federalism } & & .149 & .287 \\
\hline & & $(.683)$ & $(.697)$ \\
\hline \multirow[t]{2}{*}{ Democratic federalism } & & .549 & .593 \\
\hline & & $(.356)$ & $(.356)$ \\
\hline \multirow[t]{2}{*}{ Repressive authoritarianism } & & $-.259 *$ & $-.226 *$ \\
\hline & & $(.077)$ & $(.080)$ \\
\hline \multirow[t]{2}{*}{ Legislative partisan balance } & & -.091 & \\
\hline & & $(.060)$ & \\
\hline \multirow[t]{2}{*}{ Executive partisan balance } & & & $-.106^{\wedge}$ \\
\hline & & & $(.042)$ \\
\hline \multirow[t]{2}{*}{ Constant } & 1.419 & -1.131 & -2.206 \\
\hline & $(3.900)$ & $(3.973)$ & $(3.905)$ \\
\hline Common $\rho$ & .87 & .81 & .81 \\
\hline $\mathrm{OLS} \mathrm{R}^{2}$ & $.37 *$ & $.52 *$ & $.53 *$ \\
\hline Prais Winsten $\mathrm{R}^{2}$ & $.23 *$ & $.31 *$ & $.32 *$ \\
\hline
\end{tabular}

panel corrected standard errors in parenthesis

$* \mathrm{p} \leq .05 ; \wedge$ significant but sign of coefficient opposite of directional hypothesis; two-tailed test data source, openness and federalism; otherwise one-tailed test.

$\mathrm{N}=446$ 
